\title{
SOCIAL COGNITIVE THEORY: IMITATION AS A PREDICTOR FOR THE ADHERENCE TO PAY HEALTH INSURANCE PREMIUM
}

\author{
Nazilla Ade Nurlia'), Bhisma Murti²), Didik Gunawan Tamtomo²) \\ 1)Masters Program in Public Health, Universitas Sebelas Maret \\ 2)Faculty of Medicine, Universitas Sebelas Maret
}

\begin{abstract}
Background: Health insurance offers health care coverage to household members if all of them have paid their respective contributions, with the exception of any member insured under other medical insurance schemes. Membership is effective when each household member has, personally or through a third party, paid the required contribution regularly. This study aimed to examine the imitation as a predictor for the adherence to pay health insurance premium using social cognitive theory.

Subjects and Method: A cross sectional study was conducted at 31 sub-districts in Jember, East Java, from July to September 2020. A sample of 200 national health insurance was selected randomly. The dependent variable was adherence to pay health insurance premium. The independent variables were willingness to pay, imitation to reference group, and number of family member. The data were collected by questionnaire and analyzed using a multiple logistic regression.

Results: Adherence to pay was positively affected by willingness to pay ( $b=4.19 ; 95 \%$ $\mathrm{CI}=2.19$ to $8.04 ; \mathrm{p}<0.001)$, imitation of reference group $(\mathrm{b}=2.59 ; 95 \% \mathrm{CI}=1.39$ to $4.85 ; \mathrm{p}=0.003)$, and number of family member $(\mathrm{b}=1.90 ; 95 \% \mathrm{CI}=1.02$ to $3.56 ; \mathrm{p}=$ 0.044).

Conclusion: Adherence to pay is positively affected by willingness to pay, imitation of reference group, and number of family member.

Keywords: Adherence to pay, willingness to pay, imitation, social cognitive theory

\section{Correspondence:}

Nazilla Ade Nurlia. Masters Program in Public Health, Universitas Sebelas Maret. Jl. Ir. Sutami 36A, Surakarta 57126, Central Java. Email: nazillaade29@gmail.com. Mobile: +6281230004195 .
\end{abstract}

